\title{
Rossi, Gustavo \\ O intelectual feiticeiro: \\ Edison Carneiro e o campo de estudos das relações raciais no Brasil
}

Marc Herzman*

Campinas: Ed. Unicamp, 2015. 280 pp.

Despite the great impact of his work and his close relationships with wellknown figures in Brazilian history and historiography, Edison Carneiro has received little scholarly attention. A renowned journalist, ethnographer historian, folklorist, and activist, Carneiro left behind a rich collection of writings that, like the man himself, are frequently cited and mentioned, but have not been studied in the same way as those of white writers such as Arthur Ramos and Gilberto Freyre. Carneiro and his work, it could be said, are part of the landscape, but remain out of focus.

The absence of studies about Carneiro is especially notable considering the number of works he wrote, a vastness matched by the diversity and complexity of his life and career, which stretched from Salvador to Rio and influenced multiple generations of intellectuals and areas of culture and politics. With so many possible angles and narrative lines - and with so little written about him - the questions of where to start and end are complicated. Gustavo Rossi begins his excellent book, O Intelectual Feiticeiro: Edison Carneiro e o campo de estudos da relações raciais no Brasil, not in 1912, when Carneiro was born, but at the turn of the century, and concludes not in 1972, when Carneiro died, but in 1939, when he moved from Salvador to Rio. Those choices stem from Rossi's explicit desire not to write a biography, and the book he has produced is, indeed, much more than that.

The text is divided into three chapters. The first discusses Salvador at the turn of the century, focusing on Edison's father, Antônio Joaquim de Souza Carneiro (1881-1942), a professor at the Escola Politécnica da Bahia and a

\footnotetext{
* Associate Professor, Department of History, University of Illinois at Urbana-Champaign. Urbana, IL, USA.mahertzman@gmail.com
} 
remarkable individual in his own right. Rossi situates the Souza Carneiros within Bahia's larger political and cultural contexts, paying special attention to the family's connections to J. J. Seabra, who controlled Bahia's "political gears" between 1912 and 1924 (p. 55), and also treating poetry that Edison wrote during his youth.

Despite the rich intellectual production of both men, neither Edison nor his father left behind many written clues about their own experiences or identities. Rossi deals with this challenge via creative analysis and an innovative use of well-known sources (e.g., Thales de Azevedo's As elites de cor numa cidade brasileira) as well as more obscure ones, including documents he found at public and private archives.

Even armed with such rich sources, Rossi is the first to admit that the book does not reveal "a perfect portrait of the way that race and blackness were lived” by Carneiro and his family (p. 96). Such a portrait, no doubt, would be impossible, and Rossi's caution is well appointed. But the book forces the reader to confront questions whose answers, in many cases, will remain in dispute. Inspired by Olívia Maria Gomes da Cunha and other anthropologists who interrogate the construction of archives and the relationship between ethnography and history, Rossi frames the book not as a study about Edison's worlds, but a study with those worlds (p. 245). In other words, Rossi understands his own intellectual production as existing in dialogue with a past that we will never perfectly understand and that nonetheless influences the questions and categories that we use as scholars.

In chapter one, this approach opens questions that will surely inspire debate. Rossi suggests "at least most of the time" the Souza Carneiros "did not seem themselves and were not seen... as black" (p. 91). The observation is based in intriguing examples such as the death certificate of Antônio Joaquim, which describes the professor as "white," a point that Rossi analyzes as a sign of his limited and fragile ability to escape racism. Rossi also describes how the North American anthropologist Ruth Landes was surprised when she saw Edison for the first time. The color of his skin "was significant," Landes wrote, "because the letters of introduction came from white colleagues, who made no mention of his race or color" (p. 76). Both examples give credence to the assertion that many times Edison and his father were "not seen as blacks."

But other examples complicate that assertion. As Rossi explains, Antônio Joaquim was one of the only black professors in Salvador, and it is hard to imagine that this did not affect the perceptions of other professors and 
students, perhaps on a daily basis. One also wonders whether Landes' observation does not reveal more about her and her experiences in the U.S. than about her white colleagues, who could have defined and seen Edison one way in private, while presenting him to her in another.

This is not meant as a critique. To the contrary, these tensions underline the usefulness of Rossi's choice to work with history and all of its hard-to-see places. Rossi writes, "categories of race and blackness could be, in different moments of Carneiro's life, an important cause of tensions and disputes and feelings, not without consequences for our understanding of his practices and intellectual positions taken" (p. 93). This seems to be a more apt description than the suggestion, however well qualified, that both men were seen "most of the time" not as blacks. But one of the many strengths of this book is the way it allows for the possibility that both arguments could be true.

If the first chapter provides original perspectives about Edison and his family, the next focuses more on larger intellectual and cultural contexts, with special attention on the Academia dos Rebeldes, the literary circle created by Edison, Jorge Amado, and others in the late 1920s. There is less emphasis here on questions of race and identity than on the trajectory of the group, which functioned as a vehicle of political expression and as a kind of response to the famous modernists of São Paulo and Rio.

The rise of Getúlio Vargas in 1930 and the arrival of Juracy Magalhães as interventor of Bahia the next year signaled a transition (and decline) for the Souza Carneiros and for the state, whose oligarchic power structure fragmented. In chapter three, Rossi connects this trajectory with the evolution of Edison as a leftist militant, excavating remarkable details in his 1930s writings. Placing emphasis on his Marxist orientation and his belief in historical materialism, Rossi puts forth several stimulating arguments and observations, including the suggestion that it was Carneiro and not Freyre and Ramos whose ideas linked up most clearly with those of the "mestre" Raymundo Nina Rodrigues. Though he rejected Rodrigues's scientific racism, Carneiro, like Rodrigues, believed in the power of structure, in this case the institutions that repeatedly marginalized blacks after abolition. In Rossi's telling, that belief made Carneiro a surprising disciple of Rodrigues, whose legacy Freyre, Ramos, and others battled to claim as their own. Carneiro's work also anticipated by decades the emphasis that Florestan Fernandes would give to the relationship between race and class, a fact that deepens our understanding "of analysis of black Brazilians" (p. 206) 
during the 1930s, not to mention the important role that Carneiro played in the formulation of ideas often attributed to Fernandes and other.

Carneiro criticized Freyre, Ramos, and other scholars of black culture for lacking "the capacity to put themselves in a black body" (p. 214). He also appeared to advocate the creation of an "autonomous "black State"” (pp. 218-9), and it is worthwhile to consider whether this reflects an evolution in thought or a disparity in sources, with the more scant collection of documents from the first part of Edison's life hiding already existent ideas that were simply expressed more forcefully and clearly later, when we have more of his writing to analyze. Despite his critique of Freyre and other intellectuals, Carneiro also considered himself to be part of their circles, much closer to them than to the black men and women who he often studied. At the same time, figures like Ramos possessed privileges that he did not, evident, for example, in the position that Ramos held with the Biblioteca de Divulgação Científica (p. 228).

The book's final chapter concludes with a consideration of Carneiro and Landes, and of Carneiro's complex identity, viewed this time through the lens of a colleague, friend, and lover who saw in him a combination of, among other things, guide and "protector" (p. 233n150) and also an ethnographic subject. Through their relationship, we see how "Carneiro's 'race' was not stable or fixed [and] only made sense when inserted in other groups in that context, or when seen in relation to them" (p. 236). Rossi makes this statement at the end of the last chapter, just as Carneiro is set to leave for Rio. One supposes that the same could be said about the rest of his life, which would last another three decades and, thanks to this book, has now begun to receive the careful and intelligent treatment that it has long deserved.

Review received on August 14, 2017. Accepted on September 12, 2017. 